\title{
COMPARISON OF THREE EXTRACTION METHODS OF ALLOPURINOL IN URIC ACID HERBAL MEDICINE WITH HIGH-PERFORMANCE LIQUID CHROMATOGRAPHY QUANTIFICATION
}

\author{
RIMADANI PRATIWI, RASPATI D. MULYANINGSIH, NYI M. SAPTARINI
}

Department of Pharmaceutical Analysis and Medicinal Chemistry, Faculty of Pharmacy, Universitas Padjadjaran, Indonesia, Jalan Raya Bandung Sumedang KM. 21, Jatinangor-Sumedang 45363

Email: rimadani.pratiwi@unpad.ac.id

Received: 18 Aug 2021, Revised and Accepted: 25 Sep 2021

\section{ABSTRACT}

Objective: This study was aimed to understand and determine the effectiveness of allopurinol extraction in herbal medicine from three extraction methods based on parameters of accuracy and precision.

Methods: The study consisted of three methods including dissolving and filtering, liquid-liquid extraction, and solid-phase extraction with mixedmode cation exchanger (SPE-MCX). The procedures were carried out using $\mathrm{NaOH}$ and $\mathrm{HCl}$ in dissolving and filtering method; methanol, $\mathrm{HCl}$, and ethyl acetate in liquid-liquid extraction; and NH4OH elution solvent in SPE-MCX.

Results: The results showed that extraction effectiveness based on accuracy level was the dissolving and filtering method $>$ SPE-MCX $>$ liquid-liquid extraction with \% recovery+SD of $91.314+2.903 \%, 87.533+4.950 \%$, and $54.549+3.517 \%$, respectively. The precision level was the dissolution and filtering method $>$ SPE-MCX>liquid-liquid extraction based on \% relative standard deviations (RSD) of 3.18\%, 5.226\%, and 6.446\%, respectively.

Conclusion: It can be concluded that the allopurinol extraction method with the highest effectiveness based on accuracy and precision parameters in herbal medicine is the dissolving and filtering method.

Keywords: Allopurinol, Herbal medicine, Extraction

(C) 2021 The Authors. Published by Innovare Academic Sciences Pvt Ltd. Thisis an open access articleunder the CC BYlicense (https://creativecommons.org/licenses/by/4.0/) DOI: https://dx.doi.org/10.22159/ijap.2021.v13s4.43844 Journal homepage: https://innovareacademics.in/journals/index.php/ijap

\section{INTRODUCTION}

Gout is a condition of stiffness and joint pain due to the accumulation of monosodium urate crystals in the joints. This condition is caused by disorders of purine metabolism, in the form of excess production or decreased excretion of uric acid through the kidneys [1]. Indonesians often use traditional therapies to treat gout, one of which is by consuming herbal medicine called jamu. According to the Minister of Health of the Republic of Indonesia No. 6 of 2016 concerning the Formulary of Original Indonesian Herbal Medicines, jamu is a medicinal preparation from natural ingredients which safety and efficacy status are empirically proven [2]. The increasing demand for uric acid herbal medicine has triggered some manufacturers to carry out illegal practices in the form of adding synthetic medicinal chemicals [3]. This illegal practice is known to violate Minister of Health Regulation (Permenkes) No. 007 of 2012 Article 7 , that traditional medicine is prohibited from containing medicinal chemicals which are isolated or synthesized with medicinal properties [4]. In 2017, Food and Drug Administration (FDA) in Indonesia found 39 herbal products containing synthetic medicinal chemicals and one of which is allopurinol [5].

Allopurinol is an anti-hyperuricemia agent that inhibits xanthine oxidase enzyme to prevent uric acid production in the human body [6]. It is relatively inexpensive and effective to treat gout at adequate doses. However, adverse effects may occur such as chronic kidney disease and hypersensitivity syndrome [7]. Several studies have shown that allopurinol in herbal medicine can be identified using thinlayer chromatography (TLC) technique [8] and colorimetric paperbased analytical device [8]. The complex matrix of herbal medicine resulted in the need for a method that could extract allopurinol optimally. Developed methods to extract allopurinol include dissolving and filtering method [9], liquid-liquid extraction using organic solvent and water [10], and solid-phase extraction with mixed-mode cation exchanger (SPE-MCX) cartridge [11]. The methods are based on different extraction principles. However, no study has been found showing the effectiveness of allopurinol extraction methods from herbal medicine with the most optimal results. Extraction effectivity can be determined based on the \% recovery value [12]. It represents the amount of analyte recovered from the sample after the analysis and it is interpreted as the accuracy level of a study while the deviation of each result is evaluated using relative standard deviation (RSD) value. Thus, the effectiveness of the three methods will be determined based on the parameters of accuracy using the value of \% recovery and precision using the value of $\% \mathrm{RSD}$.

\section{MATERIALS AND METHODS}

\section{Materials}

Herbal medicine samples were purchased at street stalls, traditional medicine stores, and pharmacies in Kosambi Traditional Market, Bandung, Indonesia, and the surrounding area within $350 \mathrm{~m}$.

Chemicals used in this study were allopurinol standard (PT. Indofarma Tbk.), ammonium acetate (Merck), ammonium hydroxide 25\% (Merck), double-distilled water (API IPHA), glacial acetic acid (Merck), chloric acid 37\% (Merck), acetonitrile High-Performance Liquid Chromatography (HPLC) grade (Merck), isobutanol (Merck), filter paper (Whatman® Qualitative $110 \mathrm{~mm}$ ), ethyl acetate (SigmaAldrich), nylon filter $0.45 \mu \mathrm{m}$ (Sartorius), syringe filter $25 \mathrm{~mm}$ (Sartorius), chloroform (Merck), methanol HPLC grade (Merck), sodium hydroxide (Merck), silica gel plate $60 \mathrm{~F} 25420 \mathrm{~cm}$ x $20 \mathrm{~cm}$ (Merck Supelco ${ }^{\circledR}$ ), SPE-MCX cartridge (Oasis $\AA$ MCX Extraction cartridges $3 \mathrm{cc}$, polypropylene $30 \mu \mathrm{m} 60 \mathrm{mg}$, Waters ${ }^{\mathrm{TM}}$ ), HPLC-UV (Shimadzu LC-10 Avp UV-Vis Detector) and C18 column (LiChrosphere ${ }^{\circledR}$ 100, RP-18 $10 \mu \mathrm{m}, 25 \mathrm{~cm}$, Merck). All reagents were analytical grade unless otherwise stated.

\section{Methods}

\section{Sample collection and allopurinol identification with TLC}

Collected samples had met the criteria that there were claims to relieve or cure aches and pain, joint pain, or gout. The registration number of each sample was validated on the official website of Indonesia's FDA https://cekbpom.pom.go.id and registration status was collected.

To identify allopurinol in all samples, $400 \mathrm{mg}$ of each was dissolved in $10 \mathrm{ml}$ of $\mathrm{NaOH} 0.1 \mathrm{~N}$. Sample solutions were sonicated for $15 \mathrm{~min}$ and filtered using Whatman filter paper. Allopurinol standard 
solution (2.5 mg/ml in $\mathrm{NH}_{4} \mathrm{OH} 25 \%$ ) was also prepared as a comparison. All sample solutions and standard solutions were spotted on a silica gel plate and eluted with saturated TLC mobile phase consisted of isobutanol: $\mathrm{NH}_{4} \mathrm{OH} 25 \%$ 1:1. The eluted plates were observed under UV light at $254 \mathrm{~nm}$ [9]. The sample with a negative result was used as a positive control in TLC and used as a matrix in three extraction methods test. Positive control solution in TLC was prepared by adding $2 \mathrm{ml}$ standard solution into $2 \mathrm{ml}$ negative sample solution and eluted with the same procedure.

\section{System suitability test}

This test was aimed to obtain the best HPLC condition to separate the analyte from the matrix based on retention time $\left(\mathrm{t}_{\mathrm{R}}\right)$, capacity factor $(\mathrm{k})$, number of theoretical plates $(\mathrm{N})$, and symmetry factor (As) on the chromatogram. HPLC mobile phase consisted of acetonitrile and acetate buffer. The buffer was prepared by dissolving $770.8 \mathrm{mg}$ of ammonium acetate in $500 \mathrm{ml}$ double-distilled water. The buffer $\mathrm{pH}$ was adjusted to 4.3 with glacial acetic acid $30 \%$ in water and filtered with $0.45 \mu \mathrm{m}$ nylon. The mobile phases were sonicated for $10 \mathrm{~min}$. Allopurinol standard solution of $1 \mathrm{ppm}$ was filtered and eluted into the C18 column with mobile phase ratio at $50: 50$, flow rate $0.8 \mathrm{ml} / \mathrm{min}$, running time of $6 \mathrm{~min}$ for each injection, injection volume $20 \mu \mathrm{l}$, and detected by UV at $257 \mathrm{~nm}$ [13].

\section{Allopurinol extraction with dissolving and filtering method} (Method 1)

This method was tested on positive control solution. It was prepared by adding allopurinol standard at three levels $(40,50,60 \mathrm{mg})$ into $200 \mathrm{mg}$ matrix. The mixtures were dissolved in $5 \mathrm{ml}$ of $\mathrm{NaOH} 0.1 \mathrm{~N}$, sonicated for $15 \mathrm{~min}$ then filtered. The filtrate was added with $\mathrm{HCl}$ $0.1 \mathrm{~N}$ up to $50 \mathrm{ml}$ [9]. The solutions were diluted $100 \mathrm{x}$ and the analyte was quantified using HPLC under the same condition based on the system suitability test. The system cycle began with a blank solution, followed with triple injections of level 40, 50, and 60. Each injection was eluted in the HPLC for 6 min.

\section{Allopurinol extraction with liquid-liquid extraction (Method 2)}

Positive control mixtures at three levels were weighed and dissolved in $100 \mathrm{ml}$ methanol. The solutions were sonicated for $5 \mathrm{~min}$, stored for $96 \mathrm{~h}$ at room temperature then filtered with Whatman filter paper. The filtrates were evaporated at $50{ }^{\circ} \mathrm{C}$ to produce a concentrated extract. The extract was partitioned using $50 \mathrm{ml}$ of $\mathrm{HCl}$ $0.5 \%$ and $50 \mathrm{ml}$ of ethyl acetate for $10 \mathrm{~min}$. The mixture was alkalinized by adding $5 \mathrm{ml}$ of $\mathrm{NH}_{4} \mathrm{OH} 15 \%$ up to the $\mathrm{pH} 9$ and the partitioning was continued for another $10 \mathrm{~min}$ [10]. The aqueous phase was separated, diluted 200x then injected three times into the HPLC after a blank solution. Each injection was eluted for 6 min with the same condition based on the system suitability test.

\section{Allopurinol extraction with SPE-MCX (Method 3)}

Positive control mixtures at three levels were weighed and dissolved in $10 \mathrm{ml} \mathrm{NaOH} 0.1 \mathrm{~N}$. It was partitioned by adding chloroform $10 \mathrm{ml}$. The aqueous phase was separated, acidified with $\mathrm{HCl} 0.1 \mathrm{~N}$ until the $\mathrm{pH}$ reach 2 , filtered, and diluted 100x. An SPE cartridge was conditioned with $1 \mathrm{ml}$ methanol and $1 \mathrm{ml}$ double-distilled water. $1000 \mu \mathrm{l}$ of filtered contro solution was loaded, followed by washing with $2 \mathrm{ml}$ of acetic acid $2 \%$ and $2 \mathrm{ml}$ of methanol. The analyte was eluted with $10 \mathrm{ml}^{\circ} \mathrm{NH}_{4} \mathrm{OH} 5 \%$ in methanol. The eluted fraction was evaporated and redissolved in 10 $\mathrm{ml}$ of $\mathrm{NH}_{4} \mathrm{OH} 5 \%$ in methanol, followed by filtration and sonication for 15 min [11]. Each solution was injected three times into the HPLC after a blank solution. Each injection was eluted for 6 min with the same condition based on the system suitability test.

\section{Statistical analysis}

Data presented by \% recovery were applied to IBM SPSS 25 Statistics software to determine the difference among the methods based on accuracy and precision. It was divided into 9 groups based on concentration levels and test methods. The groups are 40method 1, 40-method 2, 40-method 3; 50-method 1, 50-method 2, 50-method 3; 60-method 1, 60-method 2, 60-method 3. Statistical difference test was performed using One Way ANOVA (Sig. $<0.05$ statistically different) $[14,15]$ followed by Tukey Post Hoc Test (Sig.<0.05 significantly different) [16] for normal and homogenous data and Kruskal-Wallis (Asymp. Sig. $<0.05$ statistically different) for abnormal and non-homogenous data [17] followed by Bonferroni Post Hoc Test (Adj. Sig.<0.05 significantly different) [16]. Normality test was performed using the Shapiro-Wilk test (Sig.>0.05 normally distributed) [18]. The method with the highest accuracy and precision was applied to positive samples later in the study.

\section{RESULTS}

Allopurinol identification results have shown that 8 out of 11 samples were not registered on Indonesia's FDA database. The registered ones are samples no. 1,2, 3, while the rest of the samples were not registered. Furthermore, all samples were applied to TLC plates for allopurinol identification.

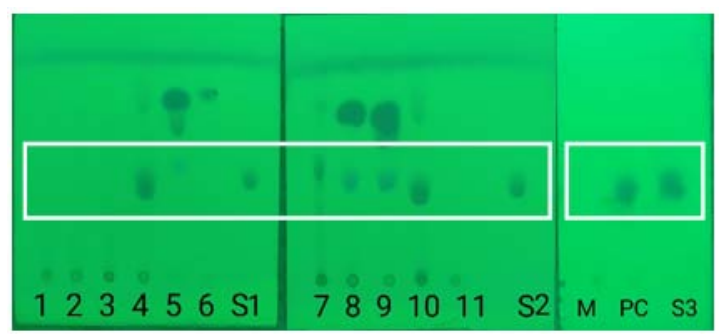

Fig. 1: TLC plates of 11 samples (left, middle) and control plate (right) with "S1" "S2" "S3" as allopurinol standard on each plate, " $\mathrm{M}$ " as a matrix, "PC" as a positive control

Table 1: Rf value of positive samples, positive control, and allopurinol standard

\begin{tabular}{ll}
\hline Sample No. & Rf value \\
\hline 4 & 0.343 \\
S1 & 0.357 \\
7 & 0.428 \\
8 & 0.400 \\
9 & 0.380 \\
10 & 0.343 \\
S2 & 0.357 \\
PC & 0.357 \\
S3 & 0.357 \\
\hline
\end{tabular}

Table 2: Chromatogram profile of allopurinol standard on system suitability test

\begin{tabular}{|c|c|c|c|c|c|c|c|}
\hline Conc. & AUC & $t_{R}$ & $t_{A}$ & $t_{B}$ & $k^{\prime}$ & $N$ & As \\
\hline $1 \mathrm{ppm}$ & 94739 & 2.623 & 2.483 & 3.400 & 2.623 & 2221.078 & 1.811 \\
\hline $1 \mathrm{ppm}$ & 95325 & 2.615 & 2.475 & 3.367 & 2.615 & 2241.643 & 1.82 \\
\hline $1 \mathrm{ppm}$ & 95047 & 2.625 & 2.442 & 3.357 & 2.625 & 2293.976 & 1.809 \\
\hline $1 \mathrm{ppm}$ & 94757 & 2.617 & 2.417 & 3.405 & 2.617 & 2177.556 & 1.815 \\
\hline $1 \mathrm{ppm}$ & 93933 & 2.620 & 2.400 & 3.342 & 2.620 & 2321.092 & 1.821 \\
\hline \multirow{2}{*}{ Average+SD } & 94780 & 2.620 & & & 2.620 & 2251.069 & 1.815 \\
\hline & +549 & +0.004 & & & +0.004 & +57.307 & +0.005 \\
\hline Literature & & & & & $1<k^{\prime}<5[20]$ & $>2000[13]$ & $0.5-2[20]$ \\
\hline
\end{tabular}

Note. "Conc." Standard allopurinol concentration; "AUC" area under the curve; " $t_{R}$ " retention time; " $t_{A}$ " peak starts; " $t_{B}$ " peak ends; " $k$ " capacity factor; " $N$ " theoretical plate; " $A s$ " symmetrical factor. 


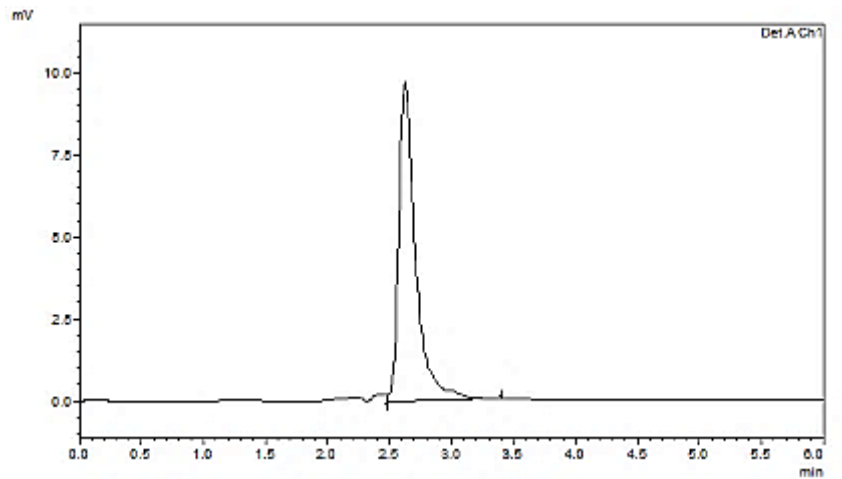

Fig. 2: Chromatogram of allopurinol standard at 1 ppm
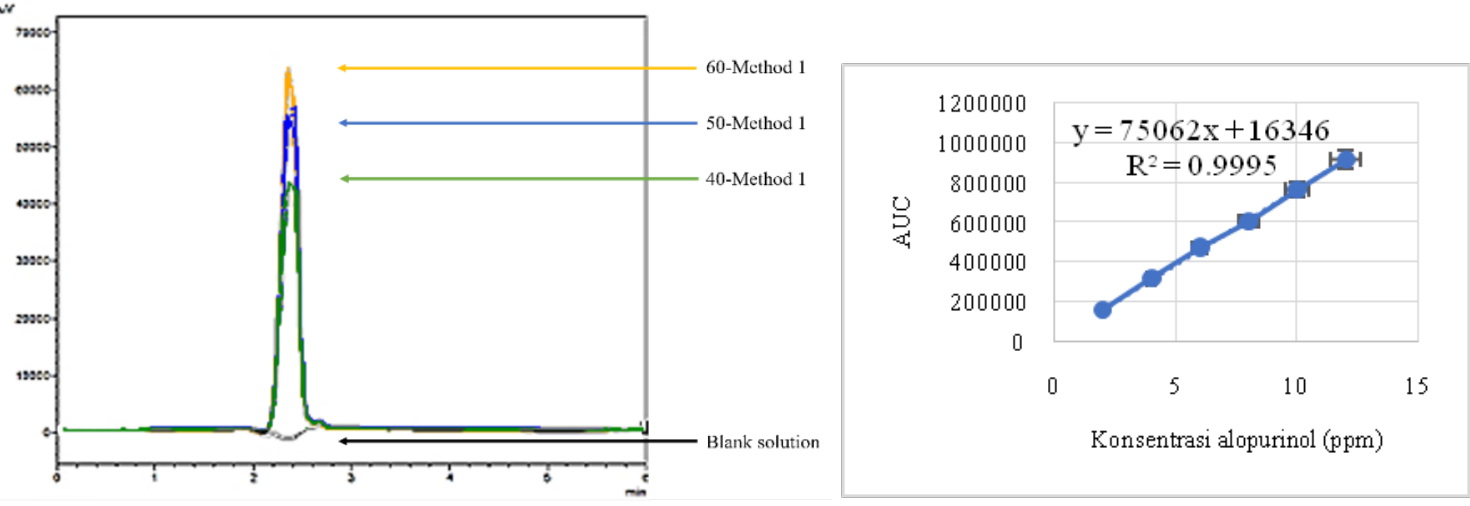

Fig. 3: Overlayed chromatogram of positive controls at 3 concentration levels and calibration curve in method 1
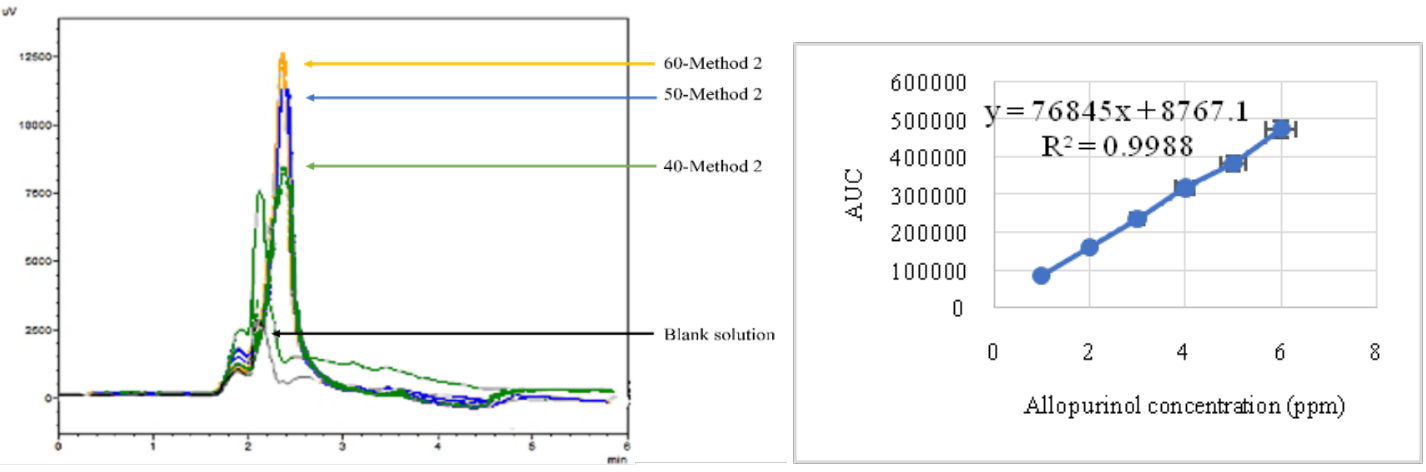

Fig. 4: Overlayed chromatogram of positive controls at 3 concentration levels and calibration curve in method 2
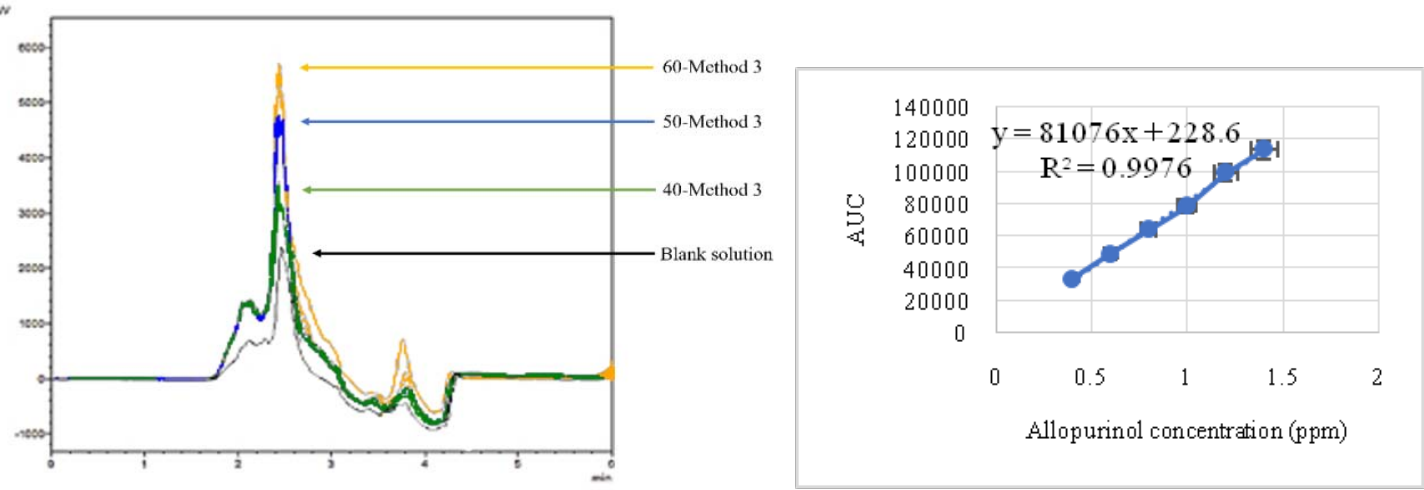

Fig. 5: Overlayed chromatogram of positive controls at 3 concentration levels and calibration curve in method 3 
Table 3: Extracted allopurinol from the method tested at 3 concentration levels

\begin{tabular}{|c|c|c|c|c|c|c|}
\hline \multirow[t]{2}{*}{ Allopurinol standard (mg) } & \multicolumn{2}{|l|}{ Method 1 } & \multicolumn{2}{|l|}{ Method 2} & \multicolumn{2}{|l|}{ Method 3} \\
\hline & \%Recovery & \%RSD & \%Recovery & \%RSD & \%Recovery & \%RSD \\
\hline 40 & 94.950 & 1.952 & 56.869 & 0.934 & 93.277 & 1.086 \\
\hline 40 & 91.511 & & 57.929 & & 91.943 & \\
\hline 40 & 92.233 & & 57.540 & & 93.925 & \\
\hline 50 & 93.592 & 1.067 & 57.069 & 2.006 & 86.536 & 3.173 \\
\hline 50 & 91.629 & & 55.241 & & 86.456 & \\
\hline 50 & 92.415 & & 55.037 & & 87.748 & \\
\hline 60 & 86.505 & 3.837 & 53.330 & 5.424 & 82.860 & 0.253 \\
\hline 60 & 92.418 & & 50.027 & & 82.445 & \\
\hline 60 & 86.570 & & 47.903 & & 82.609 & \\
\hline Average \% Recovery+SD & $91.314+2.903$ & & $54.549+3.517$ & & $87.533+4.950$ & \\
\hline Total \% RSD & 3.180 & & 6.446 & & 5.699 & \\
\hline
\end{tabular}

Table 4: Statistical different test of 3 concentration levels in 3 extraction methods

\begin{tabular}{|c|c|c|c|c|c|}
\hline \multirow{2}{*}{$\begin{array}{l}\text { Allopurinol } \\
\text { standard }\end{array}$} & \multicolumn{3}{|c|}{ Normality test (Sig.) } & \multicolumn{2}{|c|}{ Statistical different test } \\
\hline & Method 1 & Method 2 & Method 3 & P value* & Post Hoc** \\
\hline 40 & 0.383 & 0.747 & 0.623 & Sig. 0.00 & Sig. 0.988 \\
\hline 50 & 0.781 & 0.174 & 0.106 & Sig. 0.00 & Sig. 0.001 \\
\hline 60 & 0.018 & 0.762 & 0.770 & Asymp. Sig. 0.027 & Adj. Sig. 0.539 \\
\hline
\end{tabular}

*)Group of 40 and 50 were tested with Oneway ANOVA, and group of 60 was tested with Kruskal Wallis, **)Post hoc test of Tukey HSD for group of 40 and 50, and Bonferroni test for group of 60

a)

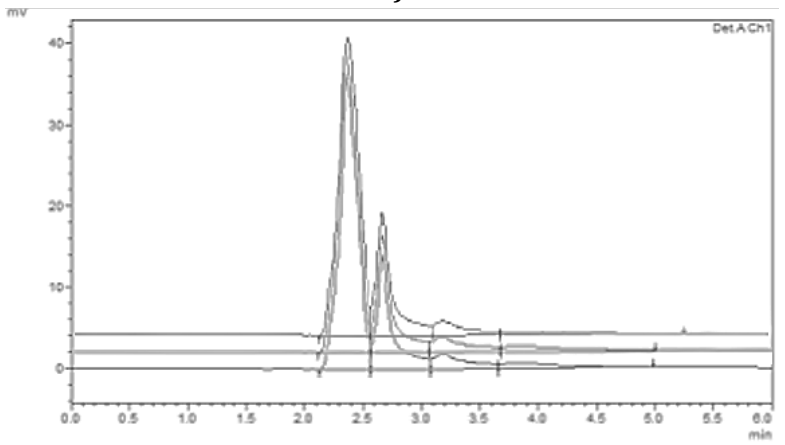

c)

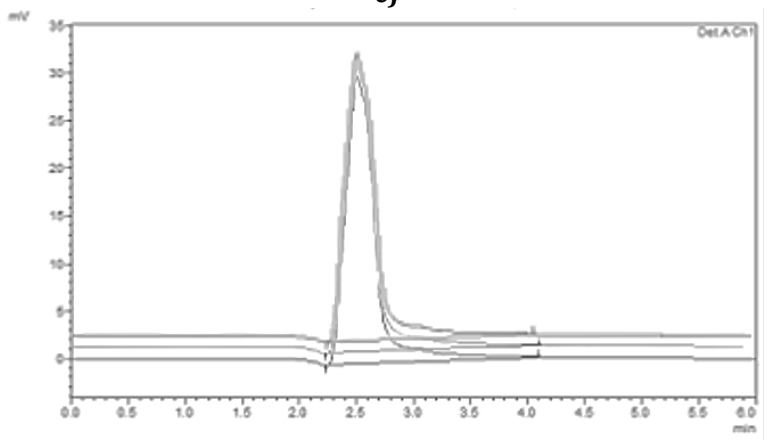

b)

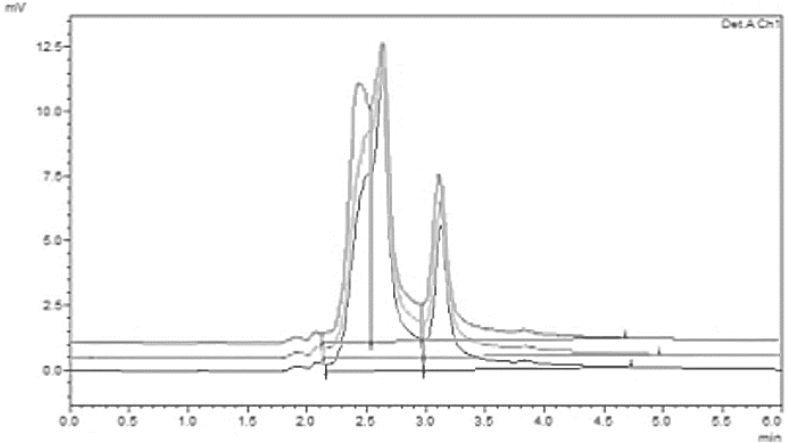

d)

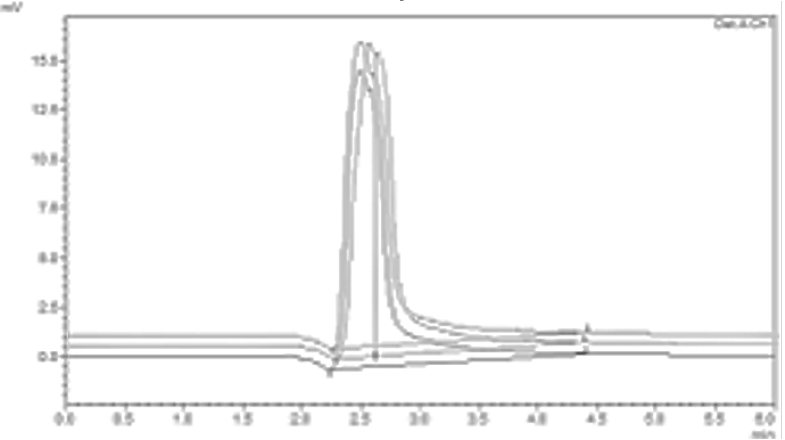

e)

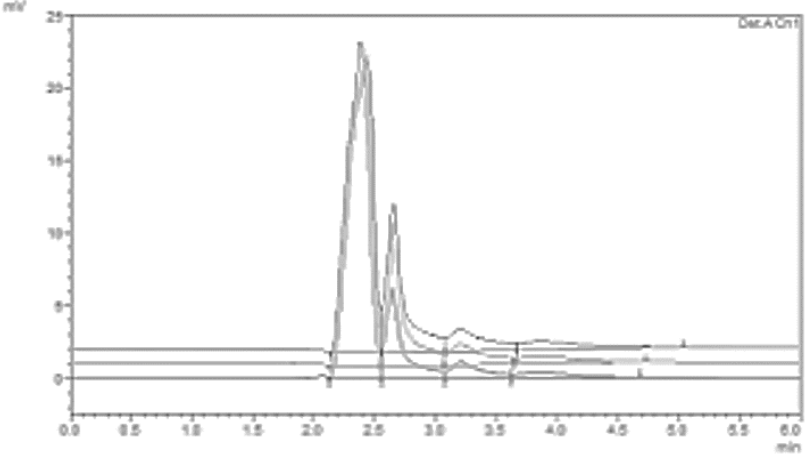

Fig. 6: Chromatograms of positive samples no. 4 (a), 7 (b), 8 (c), 9 (d), 10 (e) on method application 


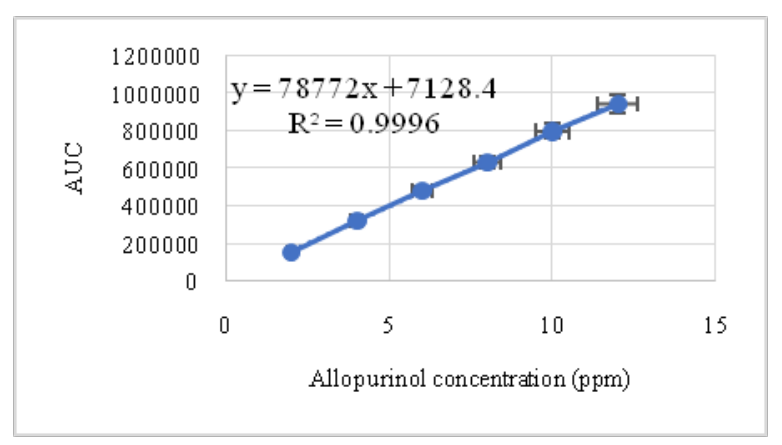

Fig. 8: Calibration curve in method application

Table 5: Allopurinol concentration in positive samples

\begin{tabular}{lll}
\hline Sample No. & Allopurinol concentration \% $\mathbf{w} / \mathbf{w})$ & \%RSD \\
\hline 4 & $10.310+0.223$ & 2.161 \\
7 & $0.501+0.008$ & 1.677 \\
8 & $70.147+0.617$ & 0.775 \\
9 & $88.689+2.726$ & 3.037 \\
10 & $7.145+0.153$ & 2.198 \\
\hline
\end{tabular}

\section{DISCUSSION}

The act of distributing non registered herbal products violates the Minister of Health Regulation (Permenkes) No. 007 of 2012 about Herbal Medicine Registration which mentions that every herbal product must be registered before they are distributed into markets. The FDA might reject proposed products that do not meet safety standards, such as the presence of synthetic medicinal chemicals. However, the rejected products might continue to enter the market by falsifying registration numbers or registering the products without adding the chemicals to obtain the distribution permit, but the permits were revoked after the illegal practices were found [19].

Based on fig. 1, 5 out of 11 samples were proven to contain allopurinol. Those were samples no. 4, 7, 8, 9, and 10. The positive samples showed a spot that results the same retention ( $\mathrm{Rf}$ value) compared to the allopurinol standard (table 1). It was calculated by the formula below and measured from elution points.

$$
\mathrm{Rf}=\frac{\text { Distance of the spot }}{\text { Distance of the mobile phase }}
$$

Some substances other than allopurinol have been spotted on the samples as well. The spots might result from secondary metabolites or other medicinal chemicals. Allopurinol is known to consist of ketone group, pyrimidine, and pyrazole rings, and is included in alkaloid group as xanthine derivative. Thus, the spots are possibly resulted by the other xanthine derivatives in the matrix. In the study reported by Rahmatullah et al., TLC also allows elution of other medicinal chemicals under the same condition of allopurinol identification [8]. According to the e-public warning database by Indonesia's FDA, sample no. 4 was confirmed to contain paracetamol and caffeine, while sample no. 9 contained paracetamol and diclofenac sodium [5]. These chemicals might also be eluted during TLC resulting in spots above allopurinol (fig. 1). Furthermore, the selection of negative samples to be used as the positive control matrix in extractions method test was carried out. The matrix selection was based on the presence or absence of spots other than allopurinol, sample registration status, and the amount of sample available. Based on these considerations, sample no. 3 was chosen as the matrix in the method test.

System suitability test was required to determine HPLC condition suitability to separate allopurinol within a short amount of time and quantify the concentration accurately in method testing. Based on table 2, allopurinol was retained in the column for $2.4 \mathrm{~min}$, then eluted up to $3.4 \mathrm{~min}$. The average peak retention time of 5 replications data was $2.620+0.004 \mathrm{~min}$ with the RSD of $0.157 \%$. This retention time is in accordance with the literature reference that the RSD value of 5 replications data is not more than $1 \%$ [13]. In addition to allopurinol retention, at 2.2 min a peak appears resulting from the unretained component (fig. 2). Based on system suitability parameters $\left(k^{\prime}, N, A s\right)$ results, the HPLC system has met the criteria to be applied on the extraction method test.

The calibration curve of each tested method was made differently, this was due to the difference in pressure on the HPLC instrument each time of testing. This pressure difference causes different detection of AUC values at the same concentrations, so that the quantitation of analyte levels is biased.

Allopurinol extraction in method 1 resulted in the same chromatogram (fig. 3) as the standard (fig. 2). In this method, allopurinol in positive control was eluted at $2.6 \mathrm{~min}$, compared to the standard which was eluted at $2.3 \mathrm{~min}$. The shift in retention time is caused by the influence of the matrix which allows interaction with the analyte so that it was eluted 0.2-0.3 min faster. Although retention time shifting occurred, the chromatogram from method 1 was still considered very good, with no peak fronting or tailing on allopurinol.

Chromatogram profiles of positive controls were collected, and AUC values were applied to the equation based on the calibration curve (fig. 3) to determine analyte concentration extracted from method 1. The results showed that the average of extracted analytes was $91.314+2.903 \%$ with a total RSD of $3.18 \%$ (table 3). During the extraction process, the matrix was noticed to precipitate as $\mathrm{HCl}$ was added into the solution. It possibly separated allopurinol from the insoluble matrix in acid and led to lowered matrix concentration in the solution.

The extraction in the method 2 involves two immiscible solvents that function to separate components in the positive control mixture based on the principle of like dissolves like. The mixtures were dissolved in methanol and partitioned with $\mathrm{HCl}$ and ethyl acetate. The analyte was expected to be dissolved in an aqueous phase and separated from the organic soluble matrix. Furthermore, the aqueous phase was alkalinized by adding $\mathrm{NH}_{4} \mathrm{OH}$. The results showed that allopurinol peaks (fig. 4) were more broadened compared to standard. The broadening was possibly influenced by different solvent compositions. Negative peaks were also noticed in the chromatogram at $4.4 \mathrm{~min}$ which could be caused by different refractive indices among the solvents, analyte, and mobile phase [21].

Allopurinol extraction in positive control using method 2 resulted in $54.549+3.517 \%$ recovery with a total RSD of $6.446 \%$ (table 3 ). The hypotheses of the low extracted allopurinol level would be the selection of methanol as the first stage solvent and the use of ethyl acetate in the partition process. Compared to method 1 where 
allopurinol was dissolved in $\mathrm{NaOH}$, in method 2 allopurinol was dissolved in methanol. Allopurinol is soluble in $\mathrm{NaOH}$, very sparingly soluble in water and ethanol [22], and less soluble in methanol [23]. It allows the extraction in method 2 to be lower than method 1 . In addition, allopurinol solubility in ethyl acetate is $0.1-1 \mathrm{~g} / \mathrm{l}$, this made partitioning less effective to separate the analyte from the matrix.

Allopurinol extraction in the method 3 was performed using packed mixed-mode cation exchanger sorbent in a $3 \mathrm{ml}$ cartridge under vacuum condition. The extraction consisted of conditioning, loading, washing, and eluting steps. Conditioning allows activation of sorbent active group $\left(-\mathrm{SO}_{3}{ }^{-}\right)$that can bind to allopurinol ions by ionic interaction with protonated nitrogen of pyrazole ring [11]. Other components that did not interact with the active group were eliminated in the washing step. The analyte was eluted from the sorbent by loading $\mathrm{NH}_{4} \mathrm{OH}$ in methanol through the sorbent.

Chromatogram resulting from method 3 showed more broadened peaks than peaks in method 2 . The negative peaks were deeper and more broadened while allopurinol peaks overlapped with another analyte eluted at 2 min (fig. 5). Deeper negative peaks were possibly caused by ammonia gas formed in the injected solution. It can be reduced by a longer duration of sonication. Extracted allopurinol from method 3 reached $87.533+4.950 \%$ recovery with a total RSD of $5.699 \%$ (table 3). The amount of extracted analyte lowers as the concentration level rises. It indicates that each method has maximum extraction capacity. The complex components in the matrix allow the presence of compounds that can interact more strongly with the sorbents, so that $10-20 \%$ of allopurinol was also eluted in the washing step. Polyphenolic compounds such as flavonols and the derivatives are known to interact with sorbents in SPE-MCX [24].

According to data presented in table 3 , the average recovery values of the method 1 and 3 were quite similar so statistical difference testing among three results was required. It is known that 1 out of 9 data groups was abnormally distributed while the rest were normally distributed. This caused different statistical methods that the group of 40 and 50 were tested with One Way ANOVA and group of 60 was tested with Kruskal-Wallis (table 4). The result showed that in all levels, the three methods were statistically different, thus the post hoc test was required. In level 40 and 60 , the difference was not significant between method 1 and 3, but it was significant in level 50. The dissimilarity of these results was obtained due to imprecise \% recovery in all groups of concentration variation (total RSD $>2 \%$ ). The reason for the different recoveries of all methods is the type of solvent used. Method 1 uses $\mathrm{NaOH}$ and $\mathrm{HCl}$ where the allopurinol is highly soluble, method 2 uses methanol and ethyl acetate where allopurinol is hardly soluble, and method 3 uses $\mathrm{NaOH}$ and elution solvent $\mathrm{NH} 4 \mathrm{OH}$ where allopurinol is highly soluble. However, it should be noted that the solvent selection in this study was in accordance with the literature procedure obtained for allopurinol extraction without any changes or optimization. The determination of the effectiveness of the extraction was carried out only based on the \% value of recovery from the three methods in the literature without an optimization to obtain the best method. The accuracy level among three methods was dissolving and filtering (method 1)>SPE-MCX (method 3)>liquid-liquid extraction (method 2), respectively. Thus, method 1 was chosen to be applied on positive samples.

The extraction was carried out on positive samples no. 4, 7, 8, 9, and 10 with three replications of each sample. The chromatograms (fig. 6) showed that in samples no. 4, 7, and 10 there were overlaps of 2 peaks while in samples no. 8 and 9 there was one peak each with the higher AUC value (table 5). Compared to TLC plates (fig. 1), there were unidentified widened spots in samples no. 8 and 9. It indicates that the unidentified components were eluted and overlapped with the allopurinol peak that led to higher AUC values. Peaks shown in chromatograms of samples no. 4, 7, and 10 were in accordance with the TLC result that there might be another peak with less AUC value than allopurinol.

In addition, according to the E-Public Warning issued by Indonesia's FDA, 2 out of 5 positive samples have been confirmed to contain synthetic medicinal chemicals. Sample no. 9 contains paracetamol and sodium diclofenac. Sample no. 4 contains paracetamol and caffeine [5]. Compared to the database, there are two hypotheses to this different result. First, manufacturers changed the type of medicinal chemicals and added allopurinol into the products after it was listed on public warning (eg. sample no. 4). This would cause a positive result on TLC although the chemical was not listed on the database. Second, method 1 was not specific enough to extract allopurinol only, so that the matrix was extracted and resulted same retention as the allopurinol standard (eg. sample no. 9).

\section{CONCLUSION}

It can be concluded that the allopurinol extraction method with the highest effectiveness based on accuracy and precision parameters in herbal medicine is the dissolving and filtering method. The method was carried out with $\mathrm{NaOH}, \mathrm{HCl}$, and filter paper, resulting in the recovery of $91.314+2.903 \%$ interpreted as accuracy level with the RSD of $3.18 \%$ as precision level.

\section{FUNDING}

Nil

\section{AUTHORS CONTRIBUTIONS}

All the authors contributed equally.

\section{CONFLICT OF INTERESTS}

\section{Declared none}

\section{REFERENCES}

1. Jaliana S, Sety L. Faktor faktor yang berhubungan dengan kejadian asam urat pada usia 20-44 di RSUD bahteramas provinsi sulawesi tenggara tahun 2017. J Ilmiah Mahasiswa Kesehatan Masyarakat. 2018;3(2):1-13.

2. Kementerian Kesehatan RI. Formularium obat Herbal asli indonesia. Jakarta: Kementerian Kesehatan RI; 2016.

3. Dalli I, Ramdhani D, Hasanah AN. Design of indicator strip using polystyrene (PS) and polymethylmethacrylate (PMMA) for detection of diclofenac sodium in traditional pain relief herbal medicines. Indones J Chem. 2017;17(1):71-8. doi: 10.22146/ijc.23612.

4. Bolendea A. Perlindungan konsumen terhadap Peredaran obat tradisional Berbahan kimia obat menurut undang-undang nomor 8 tahun 1999 tentang perlindungan konsumen. Lex Privatum. 2019;7(2):45-52.

5. Badan Pengawas Obat dan Makanan RI; 2018 [internet]. Epublic warning. Available from: https://epublicwarningotsk.pom.go. [Last accessed on 10 May 2021]

6. Okafor ON, Farrington $\mathrm{K}$, Gorog DA. Allopurinol as a therapeutic option in cardiovascular disease. Pharmacol Ther. 2017;172:139-50. doi: 10.1016/j.pharmthera.2016.12.004, PMID 27916655.

7. Stamp LK, Day RO, Yun J. Allopurinol hypersensitivity: investigating the cause and minimizing the risk. Nat Rev Rheumatol. 2016;12(4):235-42. doi: 10.1038/ nrrheum.2015.132, PMID 26416594.

8. Rahmatullah S, Slamet FA, Bahan Kimia Obat AKK. (BKO) Dalam Jamu Asam Urat yang Beredar di Kabupaten Pekalongan. URECOL Univ Res Colloqium. 2018;7:566-75.

9. Pratiwi R, Septyani RN, Febriany R, Saputri FA, Nuwarda RF. Design and optimization of colorimetric paper-based analytical device for rapid detection of allopurinol in herbal medicine. Int J Anal Chem. 2019;2019:4682839. doi: 10.1155/ 2019/4682839, PMID 31015838.

10. Shi BB, Chen J, Bao MF, Zeng Y, Cai XH. Alkaloids isolated from Tabernaemontana bufalina display xanthine oxidase inhibitory activity. Phytochemistry. 2019;166:112060. doi: 10.1016/j.phytochem.2019.112060, PMID 31302343.

11. Soenarso SA. Optimasi Isolasi Alopurinol dalam Sediaan Tablet dan Jamu. Yogyakarta: Universitas Sanata Dharma; 2014.

12. Deovita GE. Validasi metode analisis daidzein dalam wound healing patch secara reversed phase high-performance liquid chromatography. Yogyakarta: Universitas Sanata Dharma; 2018. 
13. Rajkumar B, Bhavya T, Kumar A. Reverse Phase HPLC method development and validation for the simultaneous quantitative estimation of alpha lipoic acid and allopurinol in tablets. Int J Pharm Pharm Sci. 2013;6(1):307-12.

14. Gonzales A, Herrador MA, Asuero A. Intra-laboratory assessment of method accuracy (trueness and precision) by using validation standard. Talanta. 2010;82:1995-8.

15. Kim HY. Analysis of variance (ANOVA) comparing means of more than two groups. Restor Dent Endod. 2014;39(1):74-7. doi: 10.5395/rde.2014.39.1.74, PMID 24516834

16. Lee $\mathrm{S}$, Lee DK. What is the proper way to apply the multiple comparison test? Korean J Anesthesiol. 2018;71(5):353-60. doi: $10.4097 /$ kja.d.18.00242, PMID 30157585

17. Ahammed F, Smith E. Prediction of students' performances using course analytics data: A case of water engineering course at the University of South Australia. Educ Sci. 2019;9(3):1-15. doi: $10.3390 /$ educsci9030245.

18. Ahad N, Yin T, Othman A, Yaacob C. Sensitivity of normality tests to non-normal data. Sains Malays. 2011;40(6):637-41.
19. Badan Pengawas Obat dan Makanan RI. [Public warning no]. BIN.05.03.1.43.12.17.5966 tentang Obat Tradisional Mengandung Bahan Kimia Obat. Jakarta: Badan POM; 2017.

20. Patil J, Joshi D. Various criteria in development and validation of HPLC analytical methods [review]. Int J Pharm Qual Assur. 2015;6(4):91-9.

21. Raval K, Patel H. Review on common observed HPLC troubleshooting problems. Int J Pharma Res Health Sci. 2020;8(4):3195-202. doi: 10.21276/ijprhs.2020.04.02.

22. Kementerian Kesehatan RI. Farmakope Indonesia Edisi VI. Jakarta: Kementerian Kesehatan RI; 2020.

23. Zheng M, Chen J, Chen G, Xu R, Zhao H. Solubility modeling and solvent effects of allopurinol in 15 neat solvents. J Chem Eng Data. 2018;63(9):3551-8. doi: 10.1021/acs.jced.8b00430.

24. Ruiz A, Sanhueza M, Gomez F, Tereucan G, Valenzuela T, Garcia $S$, et al. Changes in the content of anthocyanins, flavonols, and antioxidant activity in Fragaria ananass var. Camarosa fruits under traditional and organic fertilization. J Sci Food Agric. 2019;99(1):2404-10. 